\title{
HEAVY METALS CONTENT IN WHOLE BLOOD (LITERATURE REVIEW AND CASE STUDY)
}

Olena Bezkrovna ${ }^{1}$ (PhD in Biological Sciences, Associate Received: January 24, 2022 Professor), Irina Skorokhod ${ }^{2}$ (PhD in Biological Sciences), Lesya Zakrutko ${ }^{1}$ (PhD in Medical Sciences, Associate Published: February 08, 2022

Professor)

${ }^{1}$ Private higher educational establishment "Kyiv Medical

University", Kyiv, Ukraine

2 Doctor Roedger Laboratory, Kyiv, Ukraine

${ }^{*}$ Corresponding author: Olena Bezkrovna

Abstract. Heavy metals content in whole blood was analyzed for Kyiv city residents, who were tested in 2019-2020 years. According to obtained results, the metals were divided into three group. 1) with elevated concentration in statistical sample and elevated threshold (mercury and arsenic); 2) with elevated concentrations for several patients while average concentration for sample did not exceed threshold (lead); 3) with single cases of increased concentrations that are not a risk to the health of the population, but pose a threat to a particular patient
(Bi, Cd, Cr, Mo, Cs, Va). Some metals never exceeded the maximum allowable concentrations $\mathrm{Al}, \mathrm{Ba}, \mathrm{Be}, \mathrm{Au}, \mathrm{Co}, \mathrm{Cu}$, Mn, Ni, Pd, Pt, Sr, Ti, U, Zr). We recommend regular check-up for the concentrations of mercury and arsenic in blood, because these metals are the factors of population risk. When the metals concentrations in blood are elevated, the diagnosis should be established taking into account clinical history of the patient.

Keywords: heavy metals, mercury, arsen, lead, toxicology, public health.

Introduction. Nowadays, an increasing environmental and global public health concern, related with environmental contamination by heavy metals, are well known. Moreover, human exposure of these pollutants has risen dramatically because of an exponential increase of heavy metal use in several activities such as agricultural, industrial, technological and urban applications. Pollutants can penetrate to the human 
body with food, water or from air. Scientific research data confirm toxicity of heavy metals literally for all the human systems of organs. For male reproductive system it has been proven that four heavy metals (As, $\mathrm{Zn}, \mathrm{Mn}, \mathrm{Sb}$ ) were significantly and positively associated with prostate cancer risk [1] and cause spermiation defects [2].

It was shown, that $\mathrm{Ni}, \mathrm{Cu}$, and $\mathrm{Zn}$ may play a role in the pathogenesis of polycystic ovary syndrome related to reproductive hormone [3]. Levels of zinc were significantly lower in both the preeclampsia and high-risk of preeclampsia groups compared with the non-preeclampsia group [4]. Serum concentrations of $\mathrm{Zn}, \mathrm{Ni}$ and $\mathrm{Al}$ in women with endometrial polyps indicated that the serum median levels of were found to be statistically lower in the study group when compared with the control group [5]. The $\mathrm{Cu} / \mathrm{Zn}$ ratio, as a biomarker of oxidative stress, was statistically higher in the study group with endometrial polyps. It suggests the role of oxidative stress in etiopathogenesis of this disease [5].

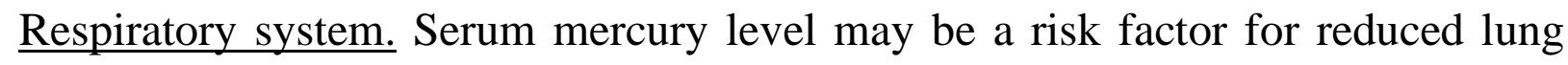
function and obstructive lung disease. A dose-response effect between increasing cadmium concentration and progressively worsening lung function was observed in smokers $[6,7]$.

Digestive system. It was suggested that disorders of metabolism of heavy metals result from impaired digestion and absorption, which are common in cirrhosis, improper diet, environmental and occupational exposure. For example, the serum concentrations of $\mathrm{Cu}, \mathrm{Zn}, \mathrm{Ni}$, and $\mathrm{Co}$ were found to be significantly lower in patients with alcoholic liver cirrhosis, while the $\mathrm{Cd}$ concentration was significantly higher compared to the control group [8]. Levels of metal in human blood depend on dietary intake both positively and negatively. The levels of arsenic, lead, and mercury showed significant differences between vegetarians and non-vegetarians. [9].

The toxic heavy metals in relatively healthy humans can be potentially hazardous. The aim of our study was to assess peculiarities of heavy metal content in the whole blood 
SSP Modern Pharmacy and Medicine (ISSN 2733-368X), Volume 2 Issue 1, Jan-Mar 2022

of patients, tested multi analysis of several metals, and to prognose adverse population health effects for this case.

Materials and methods. Heavy metals content was analyzed in the samples of whole blood, that have been taken from patients in Dr. Roedger Laboratory, Kyiv, Ukraine in frameproject of cooperation with MDI Limbach Berlin (Germany). The laboratory is accredited according to DAKS by ISO 15189.

The personal data has not been revealed in this paper except for biometric characteristics. The age varied within a range of 17 to 72 years. Totally, samples have been taken from 12 male, 10 female patients. The study has been provided in 2019-2020 years.

Inductively coupled plasma mass spectrometry (ICP-MS) was used to determine the concentrations of elements in whole blood samples. Gold, palladium, platinum, gallium, indium, iridium, copper, silver, stanum, mercury, cerium, chromium, cobalt, manganese, molybdenum, nickel, vanadium, aluminum, antimony, barium, zinc, zirconium, cadmium, titanium has been analyzed. The ICP-MS for simultaneous trace element determination in human blood has prevailed as the most suitable methodology for clinical aims because of its rapidity, detection limits and minimal sample quantity needed for analysis. In literature data it has been shown that the distribution between whole blood and serum varied considerably for different metals [10]. Therefore, the detection of heavy metals content in the whole blood is more appropriate for the purpose of our study.

Biometrical criteria have been applied to define the type of distribution and confirm the reliability of differences (tSt criterion for normal distribution) and Mana Whitney test for nonparametric distribution. The calculations have been performed in Excel program. Hypothetical group of patients with metal concentrations within allowable range, which was indicated in the multianalisis methodology, was used as a control.

Results and discussion. We divided the detected levels of heavy metals in whole blood into three groups according to obtained data (Table 1). 


\section{Group I. Significant deviation of from threshold.}

Mercury. The level of mercury was elevated in all blood samples (100\% of tested patients). The average concentration of mercury for patients' samples was 7,57士0,1 $\mu \mathrm{g} / 1$, whereas the reference range for the mercury equals $<1 \mu \mathrm{g} / 1$. The statistical confidence level has been proven with $\mathrm{t}_{\mathrm{St}}$ at level $\mathrm{p}=0,001$. The maximum elevated mercury concentration was 53,5 $\mu \mathrm{g} / \mathrm{l}$. Elevated concentrations were registered at levels 13,7 and 11,6 $\mu \mathrm{g} / 1$. The most often mercury concentration exceeded normal 4-9 times (Fig. 1). The closest to normal values were concentrations 1,3 and $1,4 \mu \mathrm{g} / \mathrm{l}$.

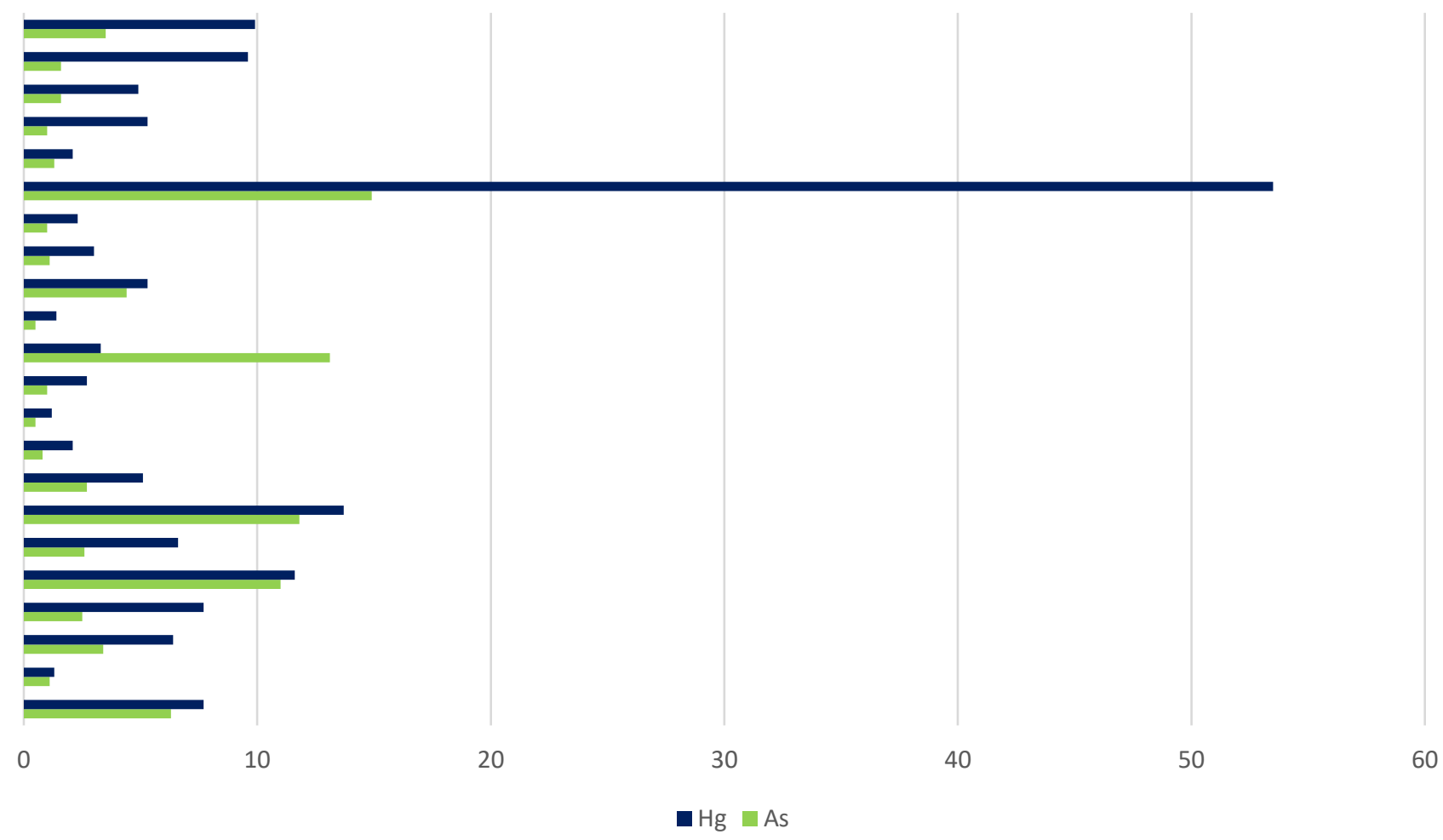

Fig. 1. Mercury and arsenic concentration in tested blood samples.

Main sources of mercury exposure: amalgam, fish, seafood, tobacco smoke, energy saving lamps, sewage sludge. With an increased content, there may be the following systemic biochemical effects: a decrease in the efficiency of detoxification, oxidative stress, allergic sensitization [11]. 
Arsenic. For arsenic the average concentration was $3,99 \pm 0,1 \mu \mathrm{g} / 1$ whereas the threshold was $<1,2 \mu \mathrm{g} / \mathrm{l}$. The following maximum concentrations were obtained: 14.9; $13.1 ; 11.8 ; 11 \mu \mathrm{g} / 1$. In 7 patients out of 22 the arsenic concentration was normal, in three more it was less than $2 \mu \mathrm{g} / \mathrm{l}$. Arsenic concentrations did not reach such high values as mercury. The sources of exposure: fish, seafood, rice, food from waste incineration, tobacco smoke, gardening. With an increased content arsenic inhibits the production and activity of ATP; blocks DNA repair [12].

All patients in the case study showed elevated blood mercury levels, arsenic concentrations were elevated in 14 patients, but the mean concentration in the sample did not exceed acceptable values. Based on the results of our study, we can conclude that the impact of these elements is a risk factor for public health, especially among residents of megacities. No correlations of these metal concentrations with age or sex were found.

Group II. Several cases of elevated concentrations without significant difference from threshold.

Lead. Four cases of elevated concentrations of lead have been registered in our study: $32,3 \mu \mathrm{g} / 1,57,7 \mu \mathrm{g} / 129,1 \mu \mathrm{g} / 1$ and 69,9 $\mu \mathrm{g} / 1$. Nevertheless, the general average was established as 18,2+_0,119 $\mu \mathrm{g} / 1$ (less than threshold). Main sources of lead: drinking water, wild mushrooms, seafood, ammunition, dust, cigarettes, tobacco smoke, electronic cigarettes, ceramic utensils, waste incineration, mineral fertilizers. At the increased content there can be the following systemic biochemical effects: disturbance of hemoglobin synthesis, decrease in efficiency of detoxification by suppression of glutathione peroxidase, formation and deposition of lead phosphate in bones and teeth, inhibition of reduction of iron and zinc, increase of need et al. [13]. 
SSP Modern Pharmacy and Medicine (ISSN 2733-368X), Volume 2 Issue 1, Jan-Mar 2022

Table 1. Concentration of heavy metals in whole blood of patients.

\begin{tabular}{|c|c|c|c|c|}
\hline Metal & $\begin{array}{l}\text { Concentration in } \\
\text { whole blood, } \\
\begin{array}{c}\mu \mathrm{g} / \mathrm{l}(\mathrm{M}+\mathrm{m}) \\
\mathrm{N}=22\end{array}\end{array}$ & $\begin{array}{c}\text { Normal range, } \\
\mu \mathrm{g} / 1\end{array}$ & $\begin{array}{c}\text { Number of cases } \\
\text { with elevated dose, } \\
\text { absolute }\end{array}$ & $\begin{array}{c}\text { Significance, } \mathrm{t}_{\mathrm{st}} \\
\alpha=0,01\end{array}$ \\
\hline \multicolumn{5}{|c|}{ Group I. } \\
\hline As & $3,99 \pm 0,1$ & $<1,2$ & 14 & $27,8 *$ \\
\hline $\mathrm{Hg}$ & $7,57 \pm 0,16$ & $<1,0$ & 22 & $41,06 *$ \\
\hline \multicolumn{5}{|c|}{ Group II } \\
\hline $\mathrm{Pb}$ & $18,2 \pm 0,99$ & $<28$ & 4 & $\mathrm{~N} / \mathrm{A}$ \\
\hline \multicolumn{5}{|c|}{ Group III } \\
\hline $\mathrm{Zn}$ & $6,08 \pm 0,05$ & $4,5-7,5$ & 2 & $\mathrm{~N} / \mathrm{A}$ \\
\hline $\mathrm{Bi}$ & $\mathrm{N} / \mathrm{A}$ & $<0,2$ & 2 & N/A \\
\hline $\mathrm{Cd}$ & $\mathrm{N} / \mathrm{A}$ & $<0,6$ & 1 & $\mathrm{~N} / \mathrm{A}$ \\
\hline $\mathrm{Cr}$ & $0,34 \underline{+0,02}$ & $0,14-0,52$ & 2 & $\mathrm{~N} / \mathrm{A}$ \\
\hline Mo & $0,42 \pm 0,1$ & $0,3-1,3$ & & $\mathrm{~N} / \mathrm{A}$ \\
\hline $\mathrm{Cs}$ & $2,89 \pm 0,05$ & $<5,3$ & & $\mathrm{~N} / \mathrm{A}$ \\
\hline $\mathrm{Va}$ & $\mathrm{N} / \mathrm{A}$ & $<0,2$ & & $\mathrm{~N} / \mathrm{A}$ \\
\hline $\mathrm{Ag}$ & $\mathrm{N} / \mathrm{A}$ & $<0,2$ & 2 & $\mathrm{~N} / \mathrm{A}$ \\
\hline
\end{tabular}


SSP Modern Pharmacy and Medicine (ISSN 2733-368X), Volume 2 Issue 1, Jan-Mar 2022

Group III. Single cases of increased concentrations, without significant difference from the threshold.

Zink. There was one case of increase and one case of decrease in concentration of $8.8 \mu \mathrm{g} / 1 \uparrow$ and $3.3 \mu \mathrm{g} / 1 \downarrow$. Reference range was 4.5-7.5 $\mu \mathrm{g} / \mathrm{l}$. Sources of improper zinc intake are: reduced resorption due to excessive supply of selenium, calcium, phosphate, copper, through alcohol; through a diet rich in phytates; through certain medications, excessive excretion through the kidneys (due to certain medications), low consumption of foods rich in zinc. Possible effects: decreased lymphocyte function; reduction of antibody production after vaccination; intestinal disorders barrier function ("Leaky gut"); increased resorption of heavy metals; disorders of collagen formation, wound healing and bone metabolism; violation neurotransmitter metabolism and hormone metabolism [14].

For chromium two elevated cases have been registered: 0,69 and 1,08 $\mu \mathrm{g} / 1$, average concentration was $0,34 \pm 0,02 \mu \mathrm{g} / \mathrm{l}$. Main sources of chromium: jewelry, endoprostheses, alloys for teeth, tobacco smoke, electronic cigarettes, tattoo inks, leather, tool kits (cutlery), dyes for color photographs, waste incineration. At the increased maintenance there can be induction of allergic sensitization [15].

Bismuth. Two cases of elevated concentrations have been registered 0,2 and 0,4 $\mu \mathrm{g} / \mathrm{l}$. The main sources of exposure: cosmetics, medicines for the treatment of Helicobacter-pylori infection (quadrotherapy), paints. With an increased content, the following systemic biochemical effects can occur: destabilization of cell membranes; at high doses, a nephrotoxic effect is possible [16].

Molybdenum. Two cases of decreased levels have been registered with values $<0,2$ $\mu \mathrm{g} / 1$ and $0,2 \mu \mathrm{g} / 1$, and one elevated case $0,3 \mu \mathrm{g} / \mathrm{l}$. Along with insufficient supply, there are the following reasons for the low value: excessive copper intake; chronic inflammation of the intestines. The case of elevated Mo is unknown. For cesium two elevated concentrations have been established: $6,1 \mu \mathrm{g} / 1$ and $6,6 \mu \mathrm{g} / 1$, the normal range less than 5,3 $\mu \mathrm{g} / 1$. 
Main sources of cesium: wild mushrooms. At high content of cesium may be the following systemic biochemical effects: DNA [17].

Vanadium. A single case of concentration of vanadium, equaled to threshold, has been registered $(0,2 \mu \mathrm{g} / 1)$. Vanadium is released in large quantities into the environment mainly by burning fossil fuels, especially oil and also from various industrial processes. Occupational exposure to vanadium concentrations is usually much higher than that of general population. High exposure causes atrophic rhinitis and bronchitis with a risk of bronchospastic effects [18].

Cadmium. A single case of elevated concentration of cadmium was registered. The concentration value was $1,2 \mu \mathrm{g} / \mathrm{l}$. The maximal acceptable concentration of cadmium is $<0,6 \mu \mathrm{g} / \mathrm{l}$. Possible sources: tobacco smoke, wild mushrooms, seafood, tattoo inks. At the increased content there can be the following effects: displacement of zinc, calcium; inhibition of selenium absorption; reducing the effectiveness of detoxification; DNA damage, decreased immune function [14].

Silver. Two cases of slightly elevated concentration have been registered: 0,25 and $0,23 \mu \mathrm{g} / 1$. Main sources: drinking water filters, antiseptics, photo development, textiles, cosmetics, amalgam and other dental alloys, jewelry, disinfection of drinking water and pool water, lozenges and chewing gum from smoking, E-cigarettes.

At the increased content there can be: reacts with thiol group and other functional groups of proteins / enzymes, destruction of cell membranes, disturbance of mitochondrial metabolism, induction of allergic sensitization [19].

Gadolinium. A concentration of $2.3 \mu \mathrm{g} / \mathrm{ml}$ was registered. Possible sources: contrast agent during MRI examination, drinking water and groundwater. Apparently, the patient had an MRI in the clinical history before being taken blood for multianalysis.

At the elevated concentration the following systemic biochemical effects may occur: at a renal failure - development of nephrogenic systemic fibrosis (NSF); blockage of Ca-channel, depositing in the bones, liver and brain. 
Gadolinium $(\mathrm{Gd})$ contrast agents are commonly used in MRI diagnosis and are considered safe. However, there was an accumulation of gadolinium in the tissues of the bones and presumably the patient's brain. In addition, gadolinium is not converted in the kidneys and enters the environment, poisoning aquatic ecosystems [20].

Concentrations of the following metals were measured, but not increased: $\mathrm{Al}, \mathrm{Ba}$, $\mathrm{Be}, \mathrm{Au}, \mathrm{Co}, \mathrm{Cu}, \mathrm{Mn}, \mathrm{Ni}, \mathrm{Pd}, \mathrm{Pt}, \mathrm{Sr}, \mathrm{Ti}, \mathrm{U}, \mathrm{Zr}$. Elevated concentrations of these potentially toxic elements were not detected in our study group.

Conclusion. Based on our study, we consider mercury and arsenic to be high risk factors for human health, lead is a threat to the health of individual patients, but its average concentration for the sample did not exceed the threshold value. Isolated cases of increased concentrations were observed for zinc, bismuth, cadmium, chromium, molybdenum, cesium, vanadium, silver. To prevent the entry of heavy metals and their subsequent toxic effects, regular check-ups, dietary restrictions, and lifestyle changes as recommended are recommended. All test results should be interpreted according to the patient's clinical history. In our case study, we do not consider toxic $\mathrm{Al}, \mathrm{Ba}, \mathrm{Be}, \mathrm{Au}, \mathrm{Co}$, $\mathrm{Cu}, \mathrm{Mn}, \mathrm{Ni}, \mathrm{Pd}, \mathrm{Pt}, \mathrm{Sr}, \mathrm{Ti}, \mathrm{U}, \mathrm{Zr}$.

Ethical approval. Ethical clearance was obtained from the administration of private higher educational establishment "Kyiv Medical University". A permission statement for conducting the experiments was received from the administration of private higher educational establishment "Kyiv Medical University". Before any data collection, the main purpose of the study was clearly explained to each department (concerned personnel).

Conflict of interests. The authors declare that they have no conflict of interests and/or competing interests.

Funding. The authors state, that there was no funding from any agencies for this study. 


\section{References.}

1. Lim J., Tan Y., Valeri L. et al. Association between serum heavy metals and prostate cancer risk - a multiple metal analysis. Environ Int. 2019. N. 132. P.105109. DOI: 10.1016/j.envint.2019.105109.

2. Jain M., Kalsi A., Srivastava A. et al. High serum estradiol and heavy metals responsible for human spermiation defect-a pilot study. J Clin Diagn Res. 2016. Vol. 10. N.12. P.RC09-RC13. DOI: 10.7860/JCDR/2016/22483.8990.

3. Zheng G., Wang L., Guo Z. et al. Association of serum heavy metals and trace element concentrations with reproductive hormone levels and polycystic ovary syndrome in a Chinese population. Biol Trace Elem Res. 2015. Vol. 167. N. 1. P. 1-10. DOI: 10.1007/s12011-015-0294-7.

4. Kolusari A., Kurdoglu M., Yildizhan R. et al. Catalase activity, serum trace element and heavy metal concentrations, and vitamin A, D and E levels in pre-eclampsia. $J$ Int Med Res. 2008. Vol.36. N.6. P.1335-1341. DOI: 10.1177/147323000803600622.

5. Yılmaz B., Evliyaoğlu Ö., Yorganc1 A. et. al. Serum concentrations of heavy metals in women with endometrial polyps. J Obstet Gynaecol. 2020. Vol. 40. N. 4. P. 541-545. DOI: 10.1080/01443615.2019.1634022.

6. Heo J., Park H., Hong Y. et al. Serum heavy metals and lung function in a chronic obstructive pulmonary disease cohort. Toxicol. Environ. Health Sci. 2017. N. 9. P. 30-35. URL: https://doi.org/10.1007/s13530-017-0300-x.

7. Rokadia H., Agarwal S. Serum heavy metals and obstructive lung disease: results from the National Health and Nutrition Examination Survey. Chest. 2013. Vol. 143. N. 2. P.388-397. DOI: 10.1378/chest.12-0595.

8. Prystupa A., Błażewicz A., Kiciński P. et al. Serum concentrations of selected heavy metals in patients with alcoholic liver cirrhosis from the Lublin Region in Eastern Poland. Int J Environ Res Public Health. 2016. Vol. 13. N. 6. P. 582. DOI: 10.3390/ijerph13060582. 
SSP Modern Pharmacy and Medicine (ISSN 2733-368X), Volume 2 Issue 1, Jan-Mar 2022

9. Jose A., Ray J. Toxic heavy metals in human blood in relation to certain food and environmental samples in Kerala, South India. Environ Sci Pollut Res Int. 2018. Vol. 25. N.8. P.7946-7953. DOI: 10.1007/s11356-017-1112-x.

10. Schultze B., Lind M., Larsson A. et al. Whole blood and serum concentrations of metals in a Swedish population-based sample Scandinavian Journal of Clinical \& Laboratory Investigation. 2014. N. 74. P. 143-148. DOI: 10.3109/00365513.2013.864785.

11. Colle D., Santos D., Moreira E. et al. Probucol increases striatal glutathione peroxidase activity and protects against 3-nitropropionic acid-induced pro-oxidative damage in rats. PLoS ONE. 2013. Vol. 8. N. 6. P.e67658. URL: https://doi.org/10.1371/journal.pone.0067658.

12. Gentry P.R., McDonald T.B., Sullivan D.E. et al. Analysis of genomic doseresponse information on arsenic to inform key events in a mode of action for carcinogenicity. Environ Mol Mutagen. 2010. Vol. 51. N. 1. P. 1-14. DOI: 10.1002/em.20505.

13. Gillis B.S., Arbieva Z., Gavin I.M. Analysis of lead toxicity in human cells. BMC Genomics. 2012. N. 13. P. 344. URL: https://doi.org/10.1186/1471-2164-13-344.

14. Tollefsen K., Scholz S., Cronin M. et al. Applying adverse outcome pathways to support integrated approaches to testing and assessment. Regulatory Toxicology and $\begin{array}{llllll}\text { Pharmacology. 2014. } & \text { Vol. } & \text { N0. } & \text { N. } & \text { P.629-640. URL: }\end{array}$ https://doi.org/10.1016/j.yrtph.2014.09.009.

15. Stern A.H., Bagdon R.E., Hazen R.E. et al. Risk assessment of the allergic dermatitis potential of environmental exposure to hexavalent chromium. J Toxicol Environ Health. 1993. Vol. 40. N. 4. P. 613-41. DOI: 10.1080/15287399309531822.

16. Leussink B.T., Nagelkerke J.F., Water B. et al. Pathways of proximal tubular cell death in bismuth nephrotoxicity. Toxicol Appl Pharmacol. 2002. Vol. 15. N. 2. P. 100109. DOI: 10.1006/taap.2002.9379. 
SSP Modern Pharmacy and Medicine (ISSN 2733-368X), Volume 2 Issue 1, Jan-Mar 2022

17. Melnikov P., Zanoni L. Clinical effects of cesium intake. Biol Trace Elem Res. 2010. Vol. 135. N. 1-3. P. 1-9. DOI: 10.1007/s12011-009-8486-7.

18. Barceloux D.G. Vanadium. J Toxicol Clin Toxicol. 1999. Vol. 37. N. 2. P. 26578. DOI: $10.1081 /$ clt-100102425.

19. Garcia-Reyero N., Kennedy A., Escalon B. et al. Differential effects and potential adverse outcomes of ionic silver and silver nanoparticles in vivo and in vitro. Environ Sci Technol. 2014. Vol. 48. N. 8. P. 4546-4555.

20. Rogowska J., Olkowska E., Ratajczyk W. et al. Gadolinium as a new emerging contaminant of aquatic environments. Environ Toxicol Chem. 2018. Vol. 37. N. 6. P. 1523-1534. DOI: 10.1002/etc.4116. 